\title{
IMPACT OF CHARACTER EDUCATION IMPLEMENTATION: A GOAL-FREE EVALUATION
}

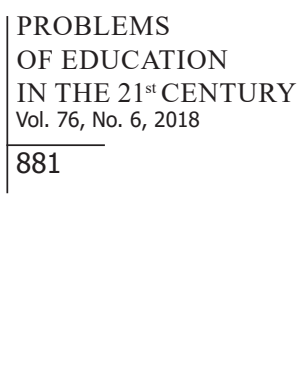

\author{
Zurqoni \\ State Islamic Institute of Samarinda, Indonesia \\ E-mail: zurqoni@iain-samarinda.ac.id,
}

Heri Retnawati, Ezi Apino, Rizqa D. Anazifa

Yogyakarta State University, Indonesia

E-mail: heri_retnawati@uny.ac.id, apinoezi@gmail.com, rizqa2011@gmail.com

\begin{abstract}
Many studies reported the importance of character education for students to support their future success. Currently, the countries have strengthened the implementation of character education in their educational system, including Indonesia. Related to the previous statements, this research aimed to describe the impact of character education implementation as well as challenges and strategies of teachers in implementing the character education. This research was an evaluation research type using a goal-free evaluation model (impact evaluation) with a qualitative approach. The participants of the research were principals, teachers, students, parents, and community members from three provinces in Indonesia; East Kalimantan, Special Region of Yogyakarta, and West Nusa Tenggara. Data were collected through Focus Group Discussion (FGD) and also in-depth interviews. The data were then analysed using a model of Bogdan and Biklen to find out the refinement among themes and generate a detailed understanding. The findings showed that character education had a positive impact on increasing the students' character values including religiosity, personality, social attitude, and competitive attitude. Role-modelling by teachers and other members of the school community and parents, character-oriented activities, and moral and material support from educational stakeholders are key factors in character education implementation. However, some improvements need to be made, such as improving the teacher training and workshops and giving financial support (funding) for character education implementation.
\end{abstract}

Keywords: character education, character value, goal-free evaluation, impact evaluation.

\section{Introduction}

Education plays an important role in establishing the quality of human resources in order to have capability to compete the challenges and the development of $21^{\text {st }}$ century era. In Indonesia, as stated in Law No. 20 Year 2003 (the Republic of Indonesia, 2003), education is aimed at developing the capability of learners to become religious, healthy, knowledgeable, capable, creative, and independent human beings as well as democratic and responsible citizens. The goal requires a balance between the cognitive ability and affective ability of learners. In other words, education in Indonesia is oriented not only to the development of thinking ability but also the development of learners' behaviour or characters.

The balance between cognitive ability and positive character of learners is one of key factors that determine the success of learners. Previous research results showed that by having a good character, learners can improve and implement the moral values and noble character, and then apply them in everyday life (Nurhasanah \& Nida, 2016); they are able to take responsible decisions (Ryan \& Bohlin, 1999), and realize the rights and duties of a good citizen (Çubukçu, 2012; McElmel, 2002). With a good character, learners would have a tendency to improve 
PROBLEMS

OF EDUCATION

IN THE $21^{\text {st }}$ CENTURY Vol. 76, No. 6, 2018

882

the academic achievement (Nurhasanah \& Nida, 2016). This suggests that a good character contributes not only to the development of social-emotional aspects but also to the cognitive aspects of learners.

It is widely considered that an educational policy known as character education can help strengthen and develop character values of learners. Abu, Mokhtar, Hassan, and Suhan (2015) stated that in the last decade, character education has been always considered in every educational design. Moreover, there is also an increasing interest in finding out a correlation between character education programs and social and academic achievements (Chang \& Muñoz, 2007). As defined by Çubukçu (2012), character education is a planned and systemic approach to educate learners to become good citizens with self-respect, responsibility and honesty. It is also defined as the deliberate attempt to influence the behaviour of students through customizing repeatedly (Abu et al., 2015), school-based process to promote personal development through the development of virtues and moral values (Pattarro, 2016). Character education is also defined as a certain curriculum that develops students' understanding of the qualities and characteristics of good character (Almerico, 2014). Thus, in general, character education can be viewed as an effort made by educational institutions to make the values of positive characters for learners.

The purpose of character education is to enable learners to understand the moral values, understand and do the right and good value, and understand the purpose of life (Battistich, 2005, Skaggs \& Bodenhorn, 2006), and improve the education quality of implementation and output in schools that lead to achieve the character building and noble character of learners as a whole, integrated, and balanced in accordance with applicable competency standards (Nurhasanah \& Nida, 2016). Character education also has a positive correlation with academic and affective aspects, as well as the establishment of positive social perceptions (Diggs \& Akos, 2016; Thompson, 2002). A study by Tannir and Al-Hroub (2013) also reported that character education has contributed to the improvement of the students' self-esteem. The purpose of character education reflects the importance of character education to support the success of learners, both in academic and social life.

Regarding the important role of character education, many countries have strengthened the implementation of character education in the respective educational systems. In Taiwan, character education is part of the curriculum through special programs called Moral and Character Education Improvement Program (MCEIP) (Lee, 2009). In the United States, character education is implemented through American Character Education Programs (Watz, 2011). In Sweden, character education became part of the curriculum and integrates in classroom learning (Skolverket, 2011). Meanwhile, in Turkey, character education is implemented through life sciences, social studies curriculum and hidden-curriculum (Demirel, 2009). In Indonesia, character education has been intensively implemented since the enactment of Competency Based Curriculum in 2004. Recently, character education continues to be implemented based on the Presidential Regulation No. 87 of 2017 (President, 2017) on Strengthening the Character Education. This Presidential Regulation certainly aims to further strengthen the role of character education in Indonesia. Technically, character education is conducted through formal, non-formal, or informal education. In formal education, the technical implementation of character education is included in the curriculum. Curriculum 2013 is the latest curriculum implemented in Indonesia and has integrated the content of character education into a learning process as stated in the Content Standard of Curriculum 2013 (the Regulation of the Minister of National Education, Number 21 of 2016). Similar to the previous curriculum (Educational Unit Level Curriculum), Curriculum 2013 also regulates the technical implementation of character education in detail.

Although the implementation of character education has been systematically arranged and included in the educational curriculum, the results of character education are not immediately 
apparent. Chang and Muñoz (2007) argued that the impact of character education can only be seen through the evaluation of a comprehensive model of character education in schools. Currently, the impacts of character education implementation, both on educational environment (school) and the surrounding community have not been clearly apparent. This is because character education is a lifelong process and continuously strengthened by real-life situations (Sprinthall \& Sprinthall, 1997). Thus, the character education implementation in the education process in Indonesia needs to be evaluated, in order to obtain accurate information related to the extent of the achievement.

Another reason for conducting evaluation of character education implementation was the challenge faced in the implementation of character education itself. The challenge might come from both internal and external factors. Internal challenges are from educational personnel (Lee, 2009, Santosa, 2014) and educational software (mind set, policy and curriculum) (Almerico, 2014). Meanwhile, the external challenges are related to the global social environment that changes the values, norm, and culture of the nation (Triatmanto, 2010; Huda, 2012; Sultoni, 2016). Other challenges include the loss of educational networks involving families (parents), schools and school environments, and communities (Huda, 2013), the use of classroom learning methods and evaluation patterns associated with the complexity of the assessment system that is not always easily agreeable to all (Sumintono, Tahir, \& Rahman, 2012), lack of facilities and infrastructure, unequal proportion between teachers and students, and students' different backgrounds (Santosa, 2014). Indeed, these challenges need to be discussed in order to find solutions.

The challenges indicate the difficulties faced in the implementation of character education. They have a big impact on the achievement of the goals of character education. In relation to this issue, evaluation of the impact of character education implementation in Indonesia needs to be immediately conducted. Impact evaluation or known as Goal-Free Evaluation (GFE) is defined as an evaluation model in which the evaluator intentionally avoids the predetermined goals of the program or the evaluator conducts an evaluation without any knowledge or reference regarding the initial objectives of the program being evaluated (Youker, 2013; Youker, Zielinski, Hunter, \& Bayer, 2016). The aim of GFE is to control the bias that usually occurs in goal -based evaluation-a bias affects the evaluator's ability to see the actual results of the program and the actual achievements. Thus, the impact evaluations are more independent or free from any intervention, and the results of the evaluation are more objective.

\section{Problem of Research}

Impact evaluation or GFE of a character education program is conducted to strengthen the implementation of character education in Indonesia. This evaluation is expected to give actual recommendations related to the implementation of character education that is more independent and objective. In addition, the evaluation results can be used as input for the government and related parties to take policies to strengthen the character education in Indonesia. Based on the background, this research aimed to describe the impact of the implementation of character education in Indonesia and discuss the contributing factors in successful implementation of character education and the components in character education that need improvement. The results of this research were expected to give a contribution to the development of character education in Indonesia and could be used as input for other countries that currently focus on strengthening character education. 


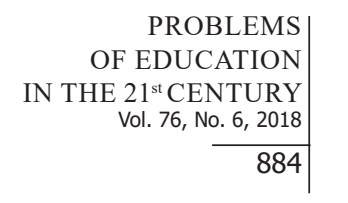

PROBLEMS

$21^{\text {st }}$ CENTURY

884

\section{Research Focus}

A study conducted by Lee (2009) has described the planning, implementation, and evaluation of character-based school culture projects in Taiwan. Meanwhile, Chang and Muñoz (2007) conducted a study focusing on the impact of character education in terms of school personnel. Several previous studies related to character education, for example Demirel (2009), Agboola and Tsai (2012), Tannir and Al-Hroub (2013), Abu et al. (2015) also only focus on uncovering obstacles and strategies in the implementation of character education based on the local context and the characteristics of students in their respective countries. This research was particularly focused on the overall evaluation (all aspects involved in the implementation of character education) based on the context of education in Indonesia. The use of the goal-free evaluation model in this research was intended to make evaluations "free" from any intervention or interest and the results are truly objective and independent based on the actual facts.

\section{Methodology of Research}

\section{General Background}

This research was evaluation research using a goal-free evaluation model (impact evaluation) with a qualitative approach. As proposed by Rossi and Freeman (1985), impact evaluation is an evaluation that measures the achievement level of a program in making a change. According to Youker (2013) goal free evaluation or evaluation of impacts consists of four steps: 1) identifying relevant impacts to examine without any reference to the goals; 2) identifying what occurs without prompting the goals; 3 ) determining what occurs and can be logically attributed to the program or intervention; 4) determining the level of the impact (positive, negative, or neutral). The scope of the research included impacts of character education, occurring in character education, implementation, evaluation, and coordination, the activities giving impacts in character education, the improvement of the students' characters, and things that need to improve in character education. The research was conducted in Indonesia, in January-July 2018.

\section{Participants}

This research was conducted at senior high schools in Indonesia that integrated religious education into learning. There were nine schools involved in this research; three senior high schools from Special Region of Yogyakarta which represents the western part of Indonesia, three senior high schools from East Kalimantan which represent the central part of Indonesia, and three senior high schools from West Nusa Tenggara which represent the eastern part of Indonesia. The three schools from each province represented three types of qualifications including high, medium, and low level.

In each school, there were nine teachers, two parents, and six students involved as the research participants, so the total participants from nine schools were 81 teachers, 18 parents, and 54 students. The teachers were directly involved in the implementation of character education at schools-including the principal, the vice principal of the curriculum, the vice principal of the student department, civic education teachers, religious teacher, and guidance and counselling teachers. They were purposefully selected because they were the spearhead of character education at senior high schools as stated in the Curriculum 2013 (the Regulation of the Minister of National Education, No. 21 of 2016). The parents involved in this research were the representative coordinators at schools who knew exactly about their children's character development. Meanwhile, the students were also involved as they were the subjects or doers in character education. 
As part of the research ethical procedures, the participants were given the opportunity prior to the research to discuss the details about the research and their involvement in this research with the researcher. To ensure anonymity, all the participants were identified with pseudonyms and all the data were kept confidential. Their participation and personal responses during this research had no effect on their academic standing and future career.

\section{Instrument and Procedures}

The data were collected through Focus Group Discussions (FGDs) and interviews. According to the initial plan, the FGDs were intended to be conducted parallel at once in three provinces. However, it might not seem feasible to carry out this plan due to a long distance between one school and the others in every province. The principals and teachers also had tight schedules which did not allow them to have the FGD together. Finally, the FGDs were conducted parallel in nine schools from February until March 2018 (one FGD in each of the schools). The participants were the principals, the vice principals, nine teachers, and two parents. The teachers invited in the FGD were those who were directly involved in the implementation of character education in each school including religious teachers (as homeroom teachers), civic education teachers, and guidance and counselling teachers. The topics for FGD were developed based on the theoretical studies related to character education and adapted to the four stages in a goal-free evaluation. The topics included the impact of character education, the things occurred in character education; evaluation and coordination in character education; activities that impacted on character education; prominent characters of students; the factors for successful character education; and things that needed to be improved in character education.

The data collection was also supported by interviews in order to sharpen the results of the FGD and at the same time allow triangulation to occur. The interviews were conducted with six students in each school as the subjects being educated in character education. The topics addressed to the students in the interview were related to the impact of character education, implementation; activities that impacted on character education; the factors for successful character education; and the programs of character education that needed to be improved.

\section{Data Analysis}

For the data analysis, a model suggested by Bogdan and Biklen (1982) was used in this research to find out the interrelations among themes and generate a detailed understanding. The analysis model consisted of three stages including data reduction, data display, and conclusion drawing. After the data were reduced into a simplified form, they were grouped based on the similarity of aspects and themes. The next step was to determine the interrelations among these themes to obtain in-depth understanding. The analysis results were then used to draw a conclusion of how much the impact of character education, i.e. positive, neutral or negative impacts. The results of the data analysis were also used to discuss many relevant topics in the implementation of character education, the improvement in students' characters and also to make recommendations related to the implementation of character education.

\section{Results of Research}

The data analysis results were categorized into seven topics including the impacts of character education, the things that occurred in character education, implementation, evaluation and coordination in character education, activities that impacted on character education, the improvement in students' characters, and things needed to be improved in character education. The data analysis results for each topic are presented in the following. 
LEMS

IN THE $21^{\text {st }}$ CENTURY Vol. 76, No. 6, 2018 886

\section{The Impacts of Character Education}

In general, character education contributed to students' behaviour changes. Based on the policy, the character education program provided schools with the opportunity to create policies aiming to maintain a balance between academic achievement and social aspects of students. Thus, character education affected not only the students but also the schools as educational institutions. In detail, the impacts of character education are presented in Table 1. Based on Table 1, the character education in schools had a positive impact on the development of student behaviour, especially in the aspects of religiosity, confidence, responsibility, cooperation, courtesy, and nationalism. The improvement in students' religiosity was shown by the increasing number of students who were engaged in daily worship at school.

The students also stated that their self-confidence increased compared to when they were in the previous educational level. For example, they were confident to express opinions, make presentations, follow the competition, and criticize inappropriate school's policy. In this case, the teachers facilitated the students to develop a sense of confidence through learning activities, extracurricular activities, and interaction with others in the surrounding community.

\section{Table 1. The impacts of character education}

\begin{tabular}{|c|c|c|}
\hline The Impacts of Character Education & Theme & $\begin{array}{l}\text { Interrelations among } \\
\text { themes }\end{array}$ \\
\hline $\begin{array}{l}\text { Students were more disciplined in practising daily prayers. } \\
\text { Students were more diligent in practising daily prayers. } \\
\text { Students acted with honesty. } \\
\text { Students showed kindness and sensitivity. } \\
\text { Students were encouraged to think positively and became } \\
\text { role models of good manners. }\end{array}$ & $\begin{array}{l}\text { Improvement in the } \\
\text { students' religiosity }\end{array}$ & \multirow{7}{*}{$\begin{array}{l}\text { The impacts of } \\
\text { character education } \\
\text { implementation were } \\
\text { apparent in the students' } \\
\text { improvement in religio- } \\
\text { sity, self-confidence, } \\
\text { responsibility, coopera- } \\
\text { tive, and nationalism. }\end{array}$} \\
\hline $\begin{array}{l}\text { Students were brave to express and share their opinions. } \\
\text { Students were brave to perform presentation in front of the } \\
\text { class. } \\
\text { Students were brave to criticise inappropriate school's } \\
\text { policy. } \\
\text { Students interacted more easily with the surrounding com- } \\
\text { munity. } \\
\text { Students were brave to compete with one another. }\end{array}$ & $\begin{array}{l}\text { Improvement in the stu- } \\
\text { dents' self-confidence }\end{array}$ & \\
\hline $\begin{array}{l}\text { Students were disciplined in tasks' completion } \\
\text { Students were more responsive and eager to get involved } \\
\text { in the school activities, such as fundraising and voluntary } \\
\text { work. } \\
\text { Students were encouraged to show leadership (leading his/ } \\
\text { her friends and coordinating with other schools) }\end{array}$ & $\begin{array}{l}\text { Improvement in the } \\
\text { students' responsible } \\
\text { attitude }\end{array}$ & \\
\hline $\begin{array}{l}\text { Students cooperated with one another in completing the } \\
\text { organizational duties or jobs. } \\
\text { Students reminded each other to practice good manners. } \\
\text { Students were more open and communicative. }\end{array}$ & $\begin{array}{l}\text { Improvement in the stu- } \\
\text { dents' cooperative ability }\end{array}$ & \\
\hline $\begin{array}{l}\text { Students were more sociable and mingled in organizations, } \\
\text { both in intracurricular and extracurricular activities. } \\
\text { Students started to reduce their selfish attitude. } \\
\text { Students collaborated with one another through activities of } \\
\text { sharing and peer teaching. }\end{array}$ & & \\
\hline $\begin{array}{l}\text { Students showed more respect to teachers and staff. } \\
\text { Students showed respect to their parents and elders. }\end{array}$ & $\begin{array}{l}\text { Improvement in the stu- } \\
\text { dents' politeness attitude } \\
\text { (courtesy) }\end{array}$ & \\
\hline $\begin{array}{l}\text { Students cared about their environment } \\
\text { Students loved domestic products. } \\
\text { Students kept the school environment clean and tidy. }\end{array}$ & $\begin{array}{l}\text { Improvement in the } \\
\text { students' nationalism }\end{array}$ & \\
\hline
\end{tabular}


The data presented in Table 1 also indicated that character education helped to promote students' religiosity, self-confidence, responsibility and cooperation. In addition, students were more encouraged to get involved in school activities, especially those which might not be explicitly connected to academic learning. These activities proved effective in developing leadership skills in the students, a sense of responsibility to perform the tasks/jobs. The improvement in cooperation attitude was shown by the students' ability to communicate effectively with others. Their good communication skills supported their improvement in collaboration skills in student clubs and organizations. These collaboration skills were also to help achieve the success of learning. The students learned together through sharing and peer teaching to help their friends comprehend a certain implemented learning material.

Character education also had impacts on the improvement in polite behaviour and nationalism. The polite behaviour was shown with the students' respect towards teachers and parents. According to the interviews with the students, however, the courtesy among the student interaction still needed improvement. There was also an increase in nationalism among the students. They showed more awareness of preserving the environment by keeping their surrounding environment clean and tidy. Moreover, the students preferred to use and love domestic goods/products. This attitude clearly reflected a sense of pride to their homeland (country).

\section{The Things Occurring in Character Education}

The next topic emerging from the data analysis was related to occurring in the implementation of character education in schools. The FGD and interviews revealed many school activities conducted by schools to strengthen the character education. These activities certainly involved a lot of expense. To anticipate the costs of the activities, the school obtained funding from its school committee, the government, and alumni donations. The details of occurring in the implementation of character education in schools are presented in Table 2.

The character building in students was facilitated by various activities as presented in Table 2. In general, these activities consisted of intra-curricular and extracurricular activities, control by the school policies and regulations, and reinforcement. The intra-curricular and extracurricular activities were organized according to the potential, talents, and interests of students. In this way, the students were given options to join in any activity they preferred. 


\section{PROBLEMS \\ OF EDUCATION \\ IN THE $21^{\text {st }}$ CENTURY \\ Vol. 76, No. 6, 2018 \\ 888 \\ Table 2. The things occurring in character education}

\begin{tabular}{|c|c|c|}
\hline The things occurring in character education & Theme & $\begin{array}{l}\text { Interrelations among the } \\
\text { themes }\end{array}$ \\
\hline $\begin{array}{l}\text { The school conducted activities to build and develop } \\
\text { character education in students, such as students' } \\
\text { orientation, achievement motivation training, state } \\
\text { defence programs, student organization, the Indone- } \\
\text { sian Red Cross, scouting, counselling groups, training } \\
\text { programs in internet utilization etc. }\end{array}$ & \multirow{3}{*}{$\begin{array}{l}\text { Activities were conducted } \\
\text { in school to instil and } \\
\text { develop good characters in } \\
\text { students. }\end{array}$} & $\begin{array}{l}\text { Activities were conducted } \\
\text { by schools to instil and } \\
\text { develop good characters in } \\
\text { students with the funding } \\
\text { from the school committee, } \\
\text { the school alumni, and the } \\
\text { government. }\end{array}$ \\
\hline $\begin{array}{l}\text { The school conducted-specific activities to strengthen } \\
\text { religious beliefs in students. } \\
\text { The school provided the students with the opportunity } \\
\text { to get involved in creating and revising the school } \\
\text { regulations and policies, every year. } \\
\text { The school gave rewards and punishments for student } \\
\text { behaviour. } \\
\text { The school conducted a regular reflection on the } \\
\text { school programs (weekly/monthly). } \\
\text { The school participated in social activities such as } \\
\text { police schooling and drug abuse counselling. }\end{array}$ & & \\
\hline $\begin{array}{l}\text { The school organized competitions among student } \\
\text { organizations. }\end{array}$ & & \\
\hline $\begin{array}{l}\text { The school strengthened the implementation of } \\
\text { character education through funding from the school } \\
\text { committee. } \\
\text { The school obtained funding for activities to support } \\
\text { character education from the government. } \\
\text { The school obtained funding for the implementation } \\
\text { of character education by seeking donations from the } \\
\text { alumni. }\end{array}$ & $\begin{array}{l}\text { The main funding support } \\
\text { for character education } \\
\text { activities was obtained } \\
\text { from the school committee, } \\
\text { the government and the } \\
\text { alumni. }\end{array}$ & \\
\hline
\end{tabular}

The support for character education was given by the school committee through the application of school rules and policies. In practice, the school rules and policies were evaluated regularly, especially in determining the sanctions for violations. The evaluation aimed to find out the effectiveness of the implementation of the school rules and policies associated with character development of students. Some schools even involved their students in creating the school rules and policies.

In addition, reinforcement techniques were used by the teachers and other members of the school community to strengthen character development in the students. Giving rewards and punishments was considered an effective way to reinforce good characters in students. Rewards were given for the students who showed outstanding achievement both in academic and non-academic learning. Moreover, personal praise from the teachers was also given to the students as a strategy to provide positive reinforcement. For example, the teacher praised the students when they helped their friends to solve problems in learning. In contrast, when the students engaged in inappropriate behaviour, the teacher imposed punishments based on the current school regulations. Another reinforcement used by the schools was conducting weekly and monthly reflection activities that facilitated by guidance and counselling teachers. In addition, the school also organized activities such as social activities, police schooling, drug abuse counselling, and competitions/races among the student organizations to strengthen the students' characters. 
Another important finding was related to operational funding support. The programs planned by the school required adequate operational costs in order to run optimally. When dealing with limited funding support, however, the schools attempted to maximize the implementation of cost-effective programs and obtain funding by seeking donations from the alumni.

\section{Implementation, Evaluation, and Coordination in Character Education}

This part addressed teachers' understanding of character education and technical implementation of character education in schools. It also explored evaluation and coordination conducted by school management in the implementation of character education. The details about implementation, evaluation, and coordination in character education are presented in Table 3. Based on Table 3, the teacher's knowledge of character education in general was sufficient. Some of the teachers even integrated character education into the subjects they taught.

Table 3. Implementation, evaluation, and coordination in character education.

\begin{tabular}{|c|c|c|}
\hline $\begin{array}{l}\text { Implementation, evaluation, and coordination in character } \\
\text { education }\end{array}$ & Theme & $\begin{array}{l}\text { Interrelations among } \\
\text { the themes }\end{array}$ \\
\hline $\begin{array}{l}\text { All of the teachers had sufficient knowledge of character educa- } \\
\text { tion and integrated it into the subjects. } \\
\text { In practice, some teachers had difficulty in integrating character } \\
\text { education into learning activities in the classroom. } \\
\text { The teachers received training in (curriculum training), whereas } \\
\text { the character education materials were only included in the } \\
\text { training. } \\
\text { The sharing session conducted by the principals and supervisors } \\
\text { provided the teachers with relevant knowledge about character } \\
\text { education. } \\
\text { The teachers were empowered through teacher forums to imple- } \\
\text { ment the local cultural values. } \\
\text { The teacher used role-modelling in character education. }\end{array}$ & $\begin{array}{l}\text { The teacher's } \\
\text { knowledge of } \\
\text { character education } \\
\text { needed to improve }\end{array}$ & $\begin{array}{l}\text { The teachers received } \\
\text { training in character } \\
\text { education, used role- } \\
\text { modelling in character } \\
\text { education and integrated } \\
\text { character education } \\
\text { into learning; evaluation } \\
\text { of the implementation } \\
\text { of character educa- } \\
\text { tion; coordination was } \\
\text { conducted through vari- } \\
\text { ous techniques among } \\
\text { teachers, principal, and } \\
\text { supervisors. }\end{array}$ \\
\hline $\begin{array}{l}\text { There was no specific evaluation of character education carried } \\
\text { out at school; evaluation was usually integrated with learning. }\end{array}$ & $\begin{array}{l}\text { Evaluation of the } \\
\text { success in character } \\
\text { education }\end{array}$ & \\
\hline
\end{tabular}
students' character development every month.

Evaluation was conducted through teacher meetings to identify problems in each class.

Each guidance and counselling teacher reported the progress of each student in character development.

Teachers guided students whom hadn't done a good manner. Evaluation related to students' character development was conducted in each semester.

\footnotetext{
Coordination was performed periodically and incidentally. The principal performed coordination tasks with the teacher in regular meetings.

The supervisors provided updated information on character education.

The school held a special workshop on character education. The teachers obtained feedback from the students related to the implementation of character education.
}

\author{
Coordination among \\ the teachers, prin- \\ cipals and school \\ supervisors
}

Interrelations among

education 
PROBLEMS

OF EDUCATION

IN THE $22^{\text {st }}$ CENTURY Vol. 76, №. 6, 2018

890

The group discussion with the teachers revealed that character education was indirectly implemented by the teachers in the learning process. Nevertheless, some teachers stated that they still had difficulty in implementing the character education. Activities conducted by the teachers during the learning process might imply the instilment in the students of the following values: discipline, confidence, responsibility, cooperation, etc. Meanwhile, to strengthen another character value such as nationalism, the teachers involved the students in more special activities, for example, a flag ceremony and other patriotic actions.

Role-modelling was admitted by the teachers to be effective in instilling character values. In this way, the teachers consistently practiced what they advised based on their current knowledge of character education. It appeared that relevant teacher training in character education helped the teachers deepen their understanding. In addition, the sharing session conducted by the principals and supervisors also provided the teachers with relevant knowledge of applying character education in accordance with their capacity and ability. However, the teachers still needed further training in how to integrate character education into the school subjects.

As admitted by the teachers and principals, there was no specific evaluation conducted for character education. The evaluation in this context was simply integrated with the implementation of instructional evaluation in each subject, contained in the assessment of attitudes. Another technique of evaluation was conducted through coordination meetings led by the principal that discussed various issues in schools including student character development. The evaluation was also conducted by the guidance and counselling teachers by monitoring the character development of the students with behavioural problems.

Regarding the discipline and sanctions, the students were involved in formulating the regulations stated in the school policy by giving inputs and suggestions. The students' involvement in this context indicated that the school succeeded in promoting justice and eliminating arbitrariness. However, the students' involvement was controlled and limited only to the regulation of minor violations.

\section{The Activities Having Impacts on Character Education}

The implementation of character education was integrated not only with the learning process in the classroom but also various activities outside the classroom. The activities contributing to character education are presented in Table 4.

Table 4. Activities having impact on character education.

\begin{tabular}{lll}
\hline Activities having impact on character education & Theme & $\begin{array}{l}\text { Interrelations among } \\
\text { the themes }\end{array}$ \\
\hline $\begin{array}{l}\text { Role-modelling by the teachers at school. } \\
\text { Role-modelling by the parents at home. }\end{array}$ & $\begin{array}{l}\text { Role-modelling by the } \\
\text { teachers at school, } \\
\text { parents at home, and } \\
\text { seniors }\end{array}$ & $\begin{array}{l}\text { The characters were } \\
\text { instilled through role- } \\
\text { modelling by the teachers } \\
\text { at school, parents at } \\
\text { home, and seniors, and } \\
\text { strengthened by school } \\
\text { activities and programs }\end{array}$ \\
$\begin{array}{l}\text { All school activities and programs had an impact on building } \\
\text { the students' character. }\end{array}$ & $\begin{array}{l}\text { The activities and } \\
\text { programs in schools to } \\
\text { strengthen the students' } \\
\text { and competitive extracurricular activities. }\end{array}$ & $\begin{array}{l}\text { chacters } \\
\text { The school regulations were consistently implemented to } \\
\text { strengthen the student characters. }\end{array}$ \\
\hline
\end{tabular}


Based on Table 4, role-modelling was very influential in developing the students' characters. In the school, the teachers were the role models for students. So, the behaviour and gestures of the teachers were observed, imitated and followed by the students. Thus, the teachers should maximally show a positive attitude in daily life, especially at school. Rolemodelling by the seniors also greatly influenced the students' characters in daily interaction and school organizations. The students' character development was also strongly influenced by parents' role-modelling. At home, the parents played a role in monitoring and guiding their children to strengthen the character values practiced at school.

Besides role-modelling, various activities were also used to facilitate the students in developing their characters. In general, the school-programmed activities were conducted to strengthen the implementation of character education in religion, sports, and culture. Various activities were also organized in the form of intracurricular and extracurricular activities to facilitate the students' interests and talents and also to build the students' characters.

Other data revealed the activities conducted in the school which implied the instilment of character values in the students. For example, activities using religious theme played an important role in building religious characters in the students. It appeared that the students became more diligently engaged in daily prayers after following religious activities routinely. Next, the students were engaged in practices of the local wisdom values, such as wearing local/ traditional costumes and local batik clothes on special days (e.g. Independence Day, National Education Day, etc.). This practice helped to introduce the local/national customs and culture and also promote nationalism. From this fact, it can be understood that the schools were aware of the importance of developing nationalistic characters in the students. Thus, the appreciation of cultural values as a way to build the character needs to be strengthened. In addition, other schools might follow such practices.

\section{Significant Improvement in the Students' Characters}

As mentioned in a previous part, one impact of character education was the improvement in students' characters and behaviour. This reflected that the teaching of character values to the students was successful or in other words, the students made improvement in their characters. From many character values taught to the students, several characters were increasingly apparent in the student behaviour as presented in Table 5.

Table 5. Significant improvement in the students' characters.

\begin{tabular}{|c|c|c|}
\hline The most noticeable characters & Theme & $\begin{array}{l}\text { Interrelations among } \\
\text { the themes }\end{array}$ \\
\hline Spirituality & Spiritual/religiosity & \multirow{5}{*}{$\begin{array}{l}\text { The improvement in the } \\
\text { students' characters were } \\
\text { apparent in the aspects } \\
\text { of spirituality, personality, } \\
\text { social attitudes, and com- } \\
\text { petitiveness }\end{array}$} \\
\hline Self-confidence & & \\
\hline $\begin{array}{l}\text { Responsibility } \\
\text { Honesty and sincerity } \\
\text { Discipline } \\
\text { Learner autonomy }\end{array}$ & Personality & \\
\hline $\begin{array}{l}\text { Cooperation and togetherness } \\
\text { Respects to older } \\
\text { Politeness }\end{array}$ & Social attitude & \\
\hline $\begin{array}{l}\text { Motivation for making progress } \\
\text { Competitive spirit } \\
\text { Communication and empathy }\end{array}$ & Competitive attitude & \\
\hline
\end{tabular}

PROBLEMS

OF EDUCATION

IN THE $21^{\text {st }}$ CENTURY

Vol. 76, No. 6, 2018

891 
OF EDUCATION

IN THE $21^{\text {st }}$ CENTURY

Vol. 76, No. 6, 2018

892

Role-modelling in various activities had a positive influence on developing the students' characters. The most noticeable characters of students were apparent in the aspects of spirituality, personality, social attitudes, and competitive spirit. The improvement in spiritual values was indicated by the increase of students' motivation to practice daily prayers. Meanwhile, the improvement in personality and social attitudes were greatly supported by the habits developed at the school such as complying with the school regulations and participating in various activities. Competitive spirit and attitudes were reflected by the students' high spirit of competition. The students' communication ability also increased along with their empathy for others.

\section{The Contributing Factors in Successful Implementation of Character Education}

The significant increase in students' character indicated that character education had a positive impact on the students. The successful implementation of character education was indeed influenced by several factors as presented in Table 6.

Table 6. The contributing factors in successful implementation of character education.

\begin{tabular}{|c|c|c|}
\hline $\begin{array}{l}\text { The contributing factors in successful implementation } \\
\text { of character education }\end{array}$ & Theme & $\begin{array}{l}\text { Interrelations among } \\
\text { the themes }\end{array}$ \\
\hline $\begin{array}{l}\text { The well-planned activities } \\
\text { Continuous and consistent commitment from the school } \\
\text { community } \\
\text { Support from the leaders, parents and communities } \\
\text { Support from the students and surrounding environment }\end{array}$ & $\begin{array}{l}\text { Commitment from } \\
\text { educational components }\end{array}$ & \multirow{5}{*}{$\begin{array}{l}\text { Contributing factors in } \\
\text { successful implementa- } \\
\text { tion of character educa- } \\
\text { tion included commitment } \\
\text { from the school communi- } \\
\text { ty, role-modelling, positive } \\
\text { activities, coordination } \\
\text { and evaluation. }\end{array}$} \\
\hline $\begin{array}{l}\text { Role-modelling from the teachers, seniors and parents } \\
\text { Continuous guidance from the teachers to the students } \\
\text { The activities within school organizations organized to ac- } \\
\text { commodate the students' talents, interests and potential }\end{array}$ & $\begin{array}{l}\text { Role-modelling and } \\
\text { positive activities }\end{array}$ & \\
\hline $\begin{array}{l}\text { The continuous coordination among the principal, teachers, } \\
\text { parents and other members of the school community. }\end{array}$ & \multirow{3}{*}{$\begin{array}{l}\text { Coordination and evalu- } \\
\text { ation }\end{array}$} & \\
\hline $\begin{array}{l}\text { Self and peer assessment for the students } \\
\text { Report on the students' achievement both in character and } \\
\text { academic performance }\end{array}$ & & \\
\hline $\begin{array}{l}\text { Monitoring the implementation of character education } \\
\text { periodically }\end{array}$ & & \\
\hline
\end{tabular}

Based on Table 6, the successful implementation of character education was influenced by a strong commitment role-modelling, positive activities, coordination and evaluation. The implementation also needed cooperation among the educational components including teachers, principals, and school committees. The character education planning also required support from the students, parents, and school environment. Role-modelling by teachers, seniors and parents was also considered as one of the most effective ways which positively contributed to the success of character education implementation. 
The successful implementation of character education was closely related to the coordination and evaluation that involved all the educational components at the school. The teachers played an important role in monitoring the students' character development periodically in order to know the students' progress or problems that might occur. The students also participated in monitoring and evaluation by completing self-monitoring sheets. The coordination with the parents is also important.

\section{Components in Character Education that Need Improvement}

Although the implementation of character education had a positive impact on improving the students' character, a number of things needed improvement. These things seen as the weaknesses of the implementation of character education today are presented in Table 7.

\section{Table 7. Components in character education that need improvement.}

\begin{tabular}{|c|c|c|}
\hline $\begin{array}{l}\text { Components in character education that need im- } \\
\text { provement }\end{array}$ & Theme & $\begin{array}{l}\text { Interrelations among the } \\
\text { themes }\end{array}$ \\
\hline $\begin{array}{l}\text { Planning and implementing the programs } \\
\text { Support and coordination between the parents and school } \\
\text { committee } \\
\text { Operational funding support }\end{array}$ & $\begin{array}{l}\text { Planning and support } \\
\text { from educational } \\
\text { stakeholders }\end{array}$ & $\begin{array}{l}\text { Components that needed im- } \\
\text { provement included planning } \\
\text { and support, short-course, } \\
\text { evaluation and follow-up. }\end{array}$ \\
\hline $\begin{array}{l}\text { Activities in teacher training and workshops on character } \\
\text { education } \\
\text { Regulation of simplification in reporting the result of } \\
\text { character education } \\
\text { Integration material in character education of local content } \\
\text { subjects }\end{array}$ & $\begin{array}{l}\text { Short-course activities } \\
\text { and regulation of } \\
\text { report simplification }\end{array}$ & \\
\hline Continuity in evaluation and follow-up & Evaluation & \\
\hline
\end{tabular}

Based on Table 7, the things that needed to improve related to the implementation of character education included planning components, support from education stakeholders, teacher training, regulatory simplification, and continuous evaluation. In the planning, some activities were not implemented effectively because of the budget limitation. The implementation also lacked support from the stakeholders as it was only dominantly managed by the teachers in the schools. Meanwhile, the involvement of the surrounding community and parents was not optimal. The teachers also complained about the lack of training and complicated regulations.

Regarding the evaluation, character education was spontaneously evaluated without the scheduled time. For that reason, the policy of character education evaluation needs to be reevaluated in the near future.

\section{The Level of Impacts of Character Education (Positive, Neutral, or Negative)}

The results related to the level of impacts of character education obtained from FGD and interviews are presented in Table 8. 


\begin{tabular}{|c|c|c|c|}
\hline $\begin{array}{r}\text { PROBLEMS } \\
\text { OF EDUCATION } \\
\text { IN THE } 21^{\text {st }} \text { CENTURY } \\
\text { Vol. } 76, \text { No. } 6,2018\end{array}$ & \multirow{2}{*}{\multicolumn{3}{|c|}{$\begin{array}{l}\text { Table 8. The level of impacts of character education (positive, neutral, or } \\
\text { negative). }\end{array}$}} \\
\hline 894 & & & \\
\hline & Level of Impacts of Character Education & Theme & $\begin{array}{l}\text { Interrelations among the } \\
\text { themes }\end{array}$ \\
\hline & $\begin{array}{l}\text { All participants stated that character education had posi- } \\
\text { tive impact, especially for the development of students' } \\
\text { behaviour. }\end{array}$ & The degree of impact & $\begin{array}{l}\text { The students' character de- } \\
\text { velopment was positive, but } \\
\text { the complexity of teachers' }\end{array}$ \\
\hline & $\begin{array}{l}\text { The teachers had much more tasks as they were required } \\
\text { to integrate and assess character values in learning. }\end{array}$ & $\begin{array}{l}\text { The increasing } \\
\text { complexity of teachers' } \\
\text { tasks }\end{array}$ & \\
\hline
\end{tabular}

Based on Table 8, the impacts of character education implementation in Indonesia according to most of the teachers are positive, especially in developing the students' character. But, the weakness of character education today is the increasing teachers' task but is not following with the increasing on in their welfare. It is certainly necessary to have a serious concern from the Indonesian government to solve the problem.

The level of impacts of character education is the final conclusion of character education evaluation, in accordance with the Goal-Free Evaluation procedure. The positive impacts of character education, as stated by the respondents (teachers and school management) are independent. It means that there is no intervention or interest for teacher in giving the statements, or intervention or interest of the researcher as the evaluator. The relevance of research findings with previous research findings and their implications for education will be described in the discussion section.

\section{Discussion}

The results showed that character education in Indonesia had a positive impact on developing the students' characters. They also provide support to the finding of a study by Agboola and Tsai (2012) that the implementation of character education in schools yields positive outcomes; decreases the number of dropouts and negative behaviour. Dodds (2016) found that character education decreased negative behaviour and increased the students' understanding of the values/characters. Character education also affects teachers' perceptions related to the importance of character education, school policies, and students' perceptions. This is relatively consistent with the findings of a study by Chang and Muñoz (2007) that character education programs have a positive impact on teacher assessment and school assessment, as well as students' perceptions.

Many factors contribute to the successful implementation of character education in Indonesia. One key factor here is the teacher as the role model in giving good examples and teaching good values to the students. According to Abu et al. (2015) many studies have reported that teachers should become good role models for their students. In addition, Thornberg and Oğuz (2013) and Lumpkin (2008) state that the main method in character education is rolemodelling by teachers in interaction with students. Thus, the character reinforcement begins from the teacher. It means that teachers need to improve their own characters, before they become a role model for their students. Teachers as role models in character education should not show a negative image in front of the students, because it will give a bad effect on the students' character development. When bad behaviour occurs among the teachers, the students might imitate it and make a habit of it. Therefore, in any circumstances, especially in schools, teachers should always provide a good example for students. 
The next contributing factor in the success of character education implementation is character habituation conducted by the schools through positive activities. Although some students felt forced to participate in the school programs at the beginning, they gradually became more diligent in following the activities. The character habituation was conducted not only through school activities but also the application of learning models aimed to strengthen the student characters. A number of studies reported some learning models used to develop character values such as Problem Based Learning (PBL) model (Schuitema, Dam, \& Veugelers, 2008; Jailani, Sugiman, \& Apino, 2017). According to Schuitema et al. (2008), problem-based learning provides students with the opportunity to make dialogues and engage in intensive social interaction. Other problem-based learning models such as Creative Problem Solving (Apino \& Retnawati, 2017) and Cooperative Learning (Matchett, 2009, Zakaria, Chin, \& Daud, 2010) are used by teachers as alternatives to teach character education. Another model called Higher Order Thinking Skills (HOTS) can be used as an alternative strategy to improve the students' character, because HOTS-oriented learning can enhance the students' active participation in learning (Retnawati, Djidu, Kartianom, Apino, \& Anazifa, 2018). The improvement in students' active participation can increase the students' curiosity, collaboration, and responsibility.

The school regulation is another important aspect which plays a prominent role in supporting character education in school institution. The success of character building such as school discipline and other values depends very much on the consistency in the school regulation-enforcement. School discipline in particular, is a type of intervention by the school to develop positive character within the students. This is relatively consistent with the finding of a research by Miller, Kraus, and Veltkamp (2005) that students who got academic intervention might experience social competence improvement. This social competence improvement indicates an increase in students' character development.

Regarding the strategies in implementing character education, the planning component is considered as a key factor. This is in accordance with the statement by Lee (2009); Zurqoni, Retnawati, Arlinwibowo, and Apino (2018) that the success of moral education programs is influenced by planning, in terms of activities/programs learning processes. The planning of activities or programs to strengthen character education should begin with a study of social phenomena, existing in the society and school community. Thus, it is necessary to improve the sensitivity of policy-makers or stakeholders of the school management in understanding relevant phenomena. The character education planning in classroom is usually designed by teachers based on applicable curriculum. The lesson plans not only contain the sequence and systematic delivery of the material (transfer of knowledge), but also integrate the character values in the process of knowledge transfer.

Although the implementation of character education in Indonesia today impacts on the students' character development quite considerably, it still has some weaknesses. In this case, the limited number of teacher training programs and workshops on character education is the main problem which needs to be immediately solved by the stakeholders. As argued by Budiarta, Artini, Seken, and Santosa (2018), intensive training and workshops are needed for teachers to improve the quality of character education implementation. Furthermore, giving more attention to financial support is also urgently needed because the program might not run optimally without adequate financial support and resources.

To find out more about the weaknesses in the implementation of character education, research-based evaluation should be performed continuously and regularly. As the study of students' character values or behaviour is very dynamic, continuity is much needed to improve any relevant program. Moreover, the outcome of character education is always encouraging for preparing the future leaders continually, and thus requires more studies especially in areas of equality/difference in character education and moral education (Agboola \& Tsai, 2012). Teachers should also conduct an integrated character education evaluation through affective 
PROBLEMS

OF EDUCATION

IN THE $21^{\text {st }}$ CENTURY Vol. 76, No. 6, 2018

896

domain assessment. Currently, the ability of Indonesian teachers in conducting an attitudinal assessment needs to be improved (Retnawati, Hadi, \& Nugraha, 2018) because teachers are as the actors and role models of character education for students.

\section{Conclusions}

The implementation of character education in the education system in Indonesia that has been running for the last two decades has made positive impacts on the development of students' characters. The character values have been significantly developed in students including religiosity, personality, social attitude, and competitive attitude. This development is supported by several factors such as role modelling by the teachers in schools and by parents at home, character-oriented activities, and moral and material support from the educational stakeholders. However, the implementation of character education in Indonesia still needs improvement in terms of training for teachers and operational funding.

As character education is believed as a way to develop qualified human resources, its implementation should be strengthened both in local and global contexts. Strengthening character education can help promote peace and harmony in the country. For that reason, support from the government such as providing training for teachers related to the technical implementation of character education is urgently needed. In addition, the education budget sector, especially for character education also needs to be increased in order to support the implementation of character education programs. The implementation of character education in Indonesia today can be a lesson for other countries in strengthening their character education. Moreover, research on implementation of character education also needs to be improved and adjusted to the current social phenomenon in order to obtain best practice in character education.

For further researchers, it is highly recommended to conduct studies related to character education in much broader contexts. Teacher training models for improving teachers' competence in implementing character education need to be carefully addressed. It is also necessary to conduct more careful research about the implementation of monitoring and evaluation including the development of evaluation models of character education, funding models, activities and instruction needed to instil good habits of character development in students. It is expected that those similar research studies can help achieve the goal of character education in improving the quality of human resources.

\section{Acknowledgements}

The authors would like to express great appreciation to the Ministry of Religion of the Republic of Indonesia for financial assistance for this research. The deepest gratitude also would go to all parties involved in this research, especially the participating schools in the Province of Daerah Istimewa Yogyakarta (Special Region of Yogyakarta), Nusa Tenggara Barat (West Nusa Tenggara), and Kalimantan Timur (East Kalimantan), Indonesia.

\section{References}

Apino, E., \& Retnawati, H. (2017). Developing instructional design to improve mathematical higher order thinking skills of students. Journal of Physics: Conference Series, 812, 1-7. doi: 10.1088/17426596/812/1/012100.

Abu, L., Mokhtar, M., Hassan, Z., \& Suhan, S. Z. D. (2015). How to develop character of madrassa students in Indonesia. Journal of Education and Learning, 9 (1), 79-86.

Agboola, A., \& Tsai, K. C. (2012). Bring character education into classroom. European Journal of Educational Research, 1 (2), 163-170. 
Almerico, G. M. (2014). Building character through literacy with children's literature. Research in Higher Education Journal, 26 (1), 1-13.

Battistich, V. (2005). Character education, prevention and youth development [Electronic version]. Retrieved October 15, 2016 from http://www.character.org/atf/cf\{77B36AC3-5057-4795-8A8F9B2FCB86F3EB \} Battistich_Paper.pdf. web.

Budiarta. L. G. R, Artini. L. P., Seken. I. K., \& Santosa, M. H. (2018). How consistent is teachers' planning, implementation, and assessment in character education? SHS Web of Conferences, 42, 1-6. doi: 10.1051/shsconf/20184200061.

Bogdan, R. C., \& Biklen, S. K. (1982). Qualitative research for education: An introduction to theory and methods. Boston, MA: Allyn and Bacon.

Chang, F., \& Muñoz, M. A. (2007). School personnel educating the whole child: Impact of character education on teacher's self-assessment and student development. Journal of Personnel Evaluation in Education, 19, 35-49. doi: 10.1007/s11092-007-9036-5.

Çubukçu, Z. (2012). The effect of hidden curriculum on character education process of primary school students. Educational Sciences: Theory \& Practice, 12 (2), 1526-1534.

Demirel, M. (2009). A review of elementary education curricula in Turkey: Values and values education. World Applied Sciences Journal, 7 (5), 670-678.

Diggs, C. R., \& Akos, P. (2016). The promise of character education in middle school: A meta-analysis, Middle Grades Review, 2 (2), 1-19.

Dodds, D. M. (2016). The effects of character education on social-emotional behavioral. Master of Arts in Education Action Research Paper. Paper 137. Retrieved October 15, 2016 from http://sophia. stkate.edu/maed.

Huda, S. (2012). Pendidikan karakter bangsa dalam perspektif global [National character education in a global perspective]. Media Akademika, 27 (3), 359-385.

Jailani, J., Sugiman, S., \& Apino, E. (2017). Implementing the problem-based learning in order to improve the students' HOTS and characters. Jurnal Riset Pendidikan Matematika, 4 (2), 247-259. doi: 10.21831 /jrpm.v4i2.17674.

Lee (Angela), Chi-Ming. (2009). The planning, implementation and evaluation of a character-based school culture project in Taiwan. Journal of Moral Education, 38 (2), 165-184.

Lumpkin, A. (2008). Teacher as role models: Teaching character and moral virtues. Journal of Physical Education, Recreation and Dance, 79 (2), 45-50.

Matchett, N. J. (2009). Cooperative learning, critical thinking, and character. Public Integrity, 12 (1), 25-38.

McElmel, S. L. (2002). Character education: A book guide of teachers, librarians, and parents. Greenwood Village, CO: Teacher Ideas Press.

Minister of Educational and Culture of The Republic of Indonesia. (2013). Peraturan Menteri Pendidikan dan Kebudayaan Nomor 21 Tahun 2016 tentang Standar Isi [Minister of Education and Culture Regulation Number 21 of 2016 concerning Content Standards]. Jakarta, Indonesia: The Ministry of Educational and Culture of the Republic of Indonesia

Miller, T. W., Kraus, R. F., \& Veltkamp, L. J. (2005). Character education as a prevention strategy in school-related violence. The Journal of Primary Prevention, 26 (5), 455-466. doi: 10.1007/ s10935-005-0004-X.

Nurhasanah, N., \& Nida, Q. (2016). Character building of students by guidance and counseling teachers through guidance and counseling services. Jurnal Ilmiah Peuradeun, 4 (1), 65-76. doi: 10.13140/ RG.2.1.3085.4160.

Pattarro, C. (2016). Character education: Themes and researches. An academic literature review. Italian Journal of Sociology of Education, 8 (1), 6-30. doi: 10.14658/pupj-ijse-2016-1-2.

President of The Republic of Indonesia (2017). Peraturan Presiden Republik Indonesia Nomor 87 Tahun 2017 tentang Penguatan Pendidikan Karakter [Presidential Regulation of the Republic of Indonesia Number 87 of 2017 concerning Strengthening Character Education]. Jakarta, Indonesia: The Ministry of State Secretariat of the Republic of Indonesia

Republic of Indonesia (2003). Undang-Undang Nomor 20 Tahun 2003 tentang Sistem Pendidikan Nasional [Law Number 20 of 2003 concerning the National Education System]. Jakarta, Indonesia. 
ZURQONI, Heri RETNAWATI, Ezi APINO, Rizqa D. ANAZIFA. Impact of character education implementation: A goal-free evaluation

PROBLEMS

OF EDUCATION

IN THE $21^{\text {st }}$ CENTURY

Vol. 76, No. 6,2018

898

Retnawati, H., Djidu, H., Kartianom, K., Apino, E., \& Anazifa, R. D. (2018). Teachers knowledge about higher-order thinking skills and its learning strategy. Problems of Education in the $21^{\text {st }}$ Century, 76 (2), 215-230.

Retnawati, H., Hadi, S., \& Nugraha, A. C. (2016). Vocational high school teachers' difficulties in implementing the assessment in Curriculum 2013 in Yogyakarta Province of Indonesia. International Journal of Instruction, 9 (1), 33-48.

Rossi, P. H., \& Freeman, H. E. (1985). Evaluation: A systematic approach. Beverly Hills, CA: Sage Publication.

Ryan, K., \& Bohlin, K. E. (1999). Building character in schools: Practical ways to bring moral instruction to life. San Fransisco, CA: Jossey-Bass.

Santosa, A. D. (2014). Implementasi pendidikan karakter dalam membangun kemandirian dan disiplin siswa di MTsN Kanigoro Kras Kab. Kediri [Character education implementation in building student independence and discipline at State Islamic Junior High School of Kanigoro Kras in District of Kediri]. Didaktika Religia, 2 (1), 21-38.

Schuitema, J., Dam, G. T., \& Veugelers, W. (2008). Teaching strategies for moral education: A review. Journal of Curriculum Studies, 40 (1), 69-89. doi: 10.1080/00220270701294210.

Skaggs, G., \& Bodenhorn, N. (2006). Relationships between implementing character education, student behavior, and student achievement. Journal of Advanced Academics, 18 (1), 82-114.

Skolverket [The National Agency for Education]. (2011). Läroplan för grundskolan, förskoleklassen och fritids-hemmet 2011 [The national curriculum policy document for the primary school, preschool classes and after-school centres]. Stockholm, Sweden: Liber Distribution.

Sprinthall, N., \& Sprinthall, L. T. (1997). How to raise a good child. In M. Josephson (Ed.), Character counts! Character development seminars (pp. 67-70). Playa del Rey, CA: Josephson Institute.

Sultoni, A. (2016). Pendidikan karakter dan kemajuan negara: Studi perbandingan lintas negara [Character education and state progress: Comparative study across countries]. Journal of Islamic Education Studies, 1 (1), 184-207.

Sumintono, B., Tahir, L. M., \& Rahman, M. A. A. (2012). Pendidikan moral di Malaysia: Tantangan dan implementasi pendidikan karakter di sekolah [Moral education in Malaysia: Challenges and implementation of character education in schools]. Jurnal Pendidikan Karakter, 2 (1), 14-22.

Tannir, A., \& Al-Hroub, A. (2013). Effects of character education on the self-esteem of intellectually able and less able elementary students in Kuwait. International Journal of Special Education, 28 (2), $1-14$.

Thompson, W. G. (2002). The effects of character education on student behavior. Electronic Theses and Dissertations. Paper 706. Retrieved from http://dc.etsu.edu/etd/706.

Thornberg, R., \& Oğuz, U. (2013). Teachers' views on values education: A qualitative study in Sweden and Turkey. International Journal of Educational Research, 59 (1), 49-56.

Triatmanto, T. (2010). Tantangan implementasi pendidikan karakter di sekolah [Challenges in implementing character education in schools]. Cakrawala Pendidikan, 29 (Special Edition), 187203.

Watz, M. (2011). An historical analysis of character education. Journal of Inquiry and Action in Education, 4 (2), 34-53.

Youker, B. W. (2013). Goal-free evaluation: A potential model for the evaluation of social work programs. Social Work Research, 37 (4), 432-438. doi: 10.1093/swr/svt032

Youker, B. W., Zielinski, A., Hunter, O. C., \& Bayer, N. (2016). Who needs goals? A case study of goalfree evaluation. Journal of Multidisciplinary Evaluation, 12 (27), 28-43.

Zakaria, E., Chin, L. C., \& Daud, M. Y. (2010). The effects of cooperative learning on students' mathematics achievement and attitude towards mathematics. Journal of Social Science, 6 (2), 272-275.

Zurqoni, Z., Retnawati. H., Arlinwibowo, J., \& Apino, E. (2018). Strategy and implementation of character education in senior high schools and vocational high schools. Journal of Social Studies Education Research, 9 (3), 370-397. 
ZURQONI, Heri RETNAWATI, Ezi APINO, Rizqa D. ANAZIFA. Impact of character education implementation: A goal-free evaluation

Received: August 15, 2018

Accepted: November 18, 2018

PROBLEMS

OF EDUCATION

IN THE $21^{\text {st }}$ CENTURY

Vol. 76, No. 6, 2018

899

\begin{tabular}{|ll|}
\hline Zurqoni Zurqoni & $\begin{array}{l}\text { Dr., Associate Professor, State Islamic Institute of Samarinda, Jl. H. A. M. Rifaddin, } \\
\text { Harapan Baru, Kec. Loa Janan llir, Kota Samarinda, Kalimantan Timur 75251, } \\
\text { Indonesia. } \\
\text { E-mail: zurqoni@iain-samarinda.ac.id }\end{array}$ \\
\hline Heri Retnawati & $\begin{array}{l}\text { Dr., Associate Professor, Yogyakarta State University, Jl. Kolombo Karangmalang } \\
\text { Yogyakarta 55281, Indonesia. } \\
\text { E-mail: heri_retnawati@uny.ac.id }\end{array}$ \\
\hline Ezi Apino & $\begin{array}{l}\text { M. Pd., Alumnus, Yogyakarta State University, Jl. Kolombo Karangmalang Yogya- } \\
\text { karta 55281, Indonesia. }\end{array}$ \\
\hline Eizqa D. Anazil: apinoezi@gmail.com
\end{tabular}

